\title{
Bromatology, food chemistry and antioxidant activity of Xanthosoma sagittifolium (L.) Schott
}

\author{
Sarah de Souza Araújo1*, Priscila de Souza Araújo', Aline Janaina Giunco', Sandro Menezes Silva², \\ Eliana Janet Sanjinez Argandoña ${ }^{1,3}$ \\ ${ }^{1}$ Faculty of Engineering, Grande Dourados Federal University, Brazil ${ }^{2}$ Faculty of Biological and Environmental Sciences, Grande Dourados \\ Federal University, Brazil; ${ }^{3}$ Post Graduate Program in Biotechnology and Biodiversity; Faculty of Biological and Environmental Sciences, \\ Grande Dourados Federal University, Brazil.
}

\section{A B S T R A C T}

\begin{abstract}
Taioba or Cocoyam - Xanthosoma sagittifolium (L.) Schott - leaves and petioles consumption is almost restricted to Brazilian traditional communities because the lack of knowledge about their chemical and nutritional features. This study was carried out to determine the Taioba leaves and petioles chemical properties (moisture, fixed mineral residue, Calcium, Magnesium, proteins, lipids, dietary fiber and carbohydrates) were quantified; Calcium oxalate was evaluated as an anti-nutritional factor. Bioactive compounds (vitamin C, chlorophyll, carotenoids, lycopene and phenolic compounds) were also determined. Antioxidant capacity was evaluated by DPPH and ABTS methods. Taioba leaves and petioles present greater quantity of proteins, fibers, Calcium, Magnesium and vitamin $\mathrm{C}$ than some conventional plants used as salad. The amount of Calcium oxalate was not considered harmful to human consume. Antioxidant activity related to Taioba bioactive compounds has functional and nutraceutical abilities, which opens promising prospects for its use.
\end{abstract}

Keywords: Unconventional food plants; Taioba; Bioactive compounds; Bromatological analysis

\section{INTRODUCTION}

There are over 3,000 potential food plant species still underexplored in Brazil, many of them being native species. Because they are naturally adapted to their natural environment they need few financial supports, are resistant to pests and diseases and grow in different types of soil and climate. Such features are important to incentive their farming and to spread their nutritional potential to people, contributing to minimize malnutrition in poorer regions (Kinupp and Lorenzi, 2014).

Unconventional Food Plants (UFP) have nutritional potential but are not include in human daily diet due to the lack of information about its use a food (Kinupp and Barros, 2008; Kinupp and Lorenzi, 2014). Many UFP contain more minerals and proteins than conventional food plants, such as leaves of Boehmeria caudata and Phenax uliginosus, with $24,15 \%$ of proteins, Mueblenbeckia sagittifolia with $27,02 \%$ and Solanum americanum with 29,9\% (Kinupp and Barros, 2008). Yet, there are few researches reporting their nutritional contents and antinutritional facts for safe human consumption (Kinupp and Lorenzi, 2014).
Xanthosoma sagittifolium (L.) Schott (Araceae) is a UFP known in Brazil as Taioba (Kinupp and Lorenzi, 2014; Caxito et al., 2015) which, along with Xanthosoma mafaffa, constitute the species of the genus with greater economic importance (Heredia Zárate et al., 2005). Taioba is grown and consumed in some regions of Africa, Asia and (Kobori and Rodriguez-amaya, 2008; Jackix et al., 2013; Caxito et al., 2015); in South America its leaves are eaten steamed (Jackix et al., 2013) and braised (MAPA, 2010), and in Brazil there are reports of its consumption in the States of Bahia, Minas Gerais, Rio de Janeiro and Espírito Santo (Seganfredo et al., 2001). In Amazon region Taioba corms are used in traditional diet, but the leaves are often discarded (Pérez et al., 2007; Jackix et al., 2013).

Taioba farming is simple and has low cost with high productivity; its leaves can be cut from 60 to 75 days after planting and it yields nearly $6,000 \mathrm{~kg} / \mathrm{ha}$ (MAPA, 2010). Almost all the plant body is used for human consumption - corms, leaves, petioles and inflorescences (Falade and Okafor, 2015). The species can be grown in regions with more than $20^{\circ} \mathrm{C}$ (MAPA, 2010), which makes it an important alternative for family farming (Souza, 2008). 
Taioba leaves are excellent sources of calcium, phosphorus, iron (Caxito et al., 2015) and vitamin C (Pinto et al., 2001b), but the fibers are their main constituents (Jackix et al., 2013). Reducing intake of Calcium and Magnesium in the diet exposes individuals to the risk of chronic diseases (Jahnen-Dechent and Ketteler, 2012). Calcium is stored mainly in the bones and plays an important structural role, and, outside the skeleton, control various cellular processes such as muscle contraction, neuronal transmission, hormone secretion, organelle communication, cell motility, fertilization and cell growth (Arruda and Hotamisligil, 2015). Magnesium is important for the proper functioning of the Central Nervous System, playing an important role in the control of Alzheimer's disease since it prevents memory decline; also works in the control of diabetes, hypertension, migraine, hyperactivity and attention deficit, as well as preventing stroke (Wang et al., 2018).

Although Taioba has nutritional value and food potential, the plant may contain anti-nutritional factors that reduce its consumption (Pinto et al., 2001a). Knowing the nutricional and anti-nutritional components and the bioactive compounds from leaves and petioles of this plant, that are the least used parts as food, is important to include them in human diet in a safety and effective way thus being considered as an alternative or complementary food. The goal of the study was to determine the nutritional and functional properties of leaves and petioles of Taioba, beyond evaluate calcium oxalate contents to detect anti-nutritional factors.

\section{METHODS}

\section{Botanical material}

Taioba fresh leaves and petioles (Xanthosoma sagittifolium (L.) Schott) were randomly collected in the morning, between 60-75 days after planting in 2017, from the individual cultivated at Horta Didática Agroecológica of Grande Dourados Federal University (UFGD) in Dourados, Mato Grosso do Sul State, Brazil (Latitude 22 13 ' $18^{\prime \prime} \mathrm{S}$ e Longitude de $\left.54^{\circ} 48^{\prime} 23^{\prime \prime} \mathrm{W}\right)$. The voucher was deposited in the herbarium of Grande Dourados Federal University (DDMS) under the number 6009.

The leaves were separated from the petioles and both were manually chopped, sanitized by immersion for 10 minutes in a $0,66 \%$ dehydrated sodium dichloroisocyanurate solution, washed in potable water and slightly dried with paper to then be crushed into the processor, put in flexible polypropylene packaging and stored at $-10^{\circ} \mathrm{C}$ until the time of use.

\section{Chemical analysis}

Humidity contents were determined in air circulation oven at $105^{\circ} \mathrm{C}(\mathrm{AOAC}, 2003)$, mineral contents in mufla oven at
$550{ }^{\circ} \mathrm{C}$ (AOAC, 2003), protein and lipids contents according to AOAC (2003) and food fiber according to AOAC (2005). Total carbohydrates were calculated by difference (100 ggrams of humidity, protein, lipids and minerals).

Calcium and magnesium were determined by Nitricperchloric digestion and the mineral elements were quantified by spectrophotometry of atomic absorption (Malavolta et al., 1997). The analyzes were performed in triplicate and the results expressed in $\mathrm{g} / 100 \mathrm{~g}$ of sample on dry basis and standard deviation.

Calcium oxalate contents in leaves and petioles were determined according to Iwoha and Kalu (1995) following the three steps: digestion, calcium oxalate precipitation and potassium permanganate titration. Initially $25 \mathrm{~g}$ of sample was mixed with $190 \mathrm{~mL}$ of distilled water and $10 \mathrm{~mL}$ of $\mathrm{HCl}(6 \mathrm{M})$, heated $\left(100{ }^{\circ} \mathrm{C} / 1 \mathrm{~h}\right)$ and then cooled in ice bath. The volume was completed com distilled water up to $250 \mathrm{~mL}$ and filtered by vacuum.

To $125 \mathrm{ml}$ aliquots of the filtrate were added 4 drops of Methyl Red solution (0,1\%), then NH4OH P.A was added by dripping till the color changed from salmonrose $(\mathrm{pH} 4-4.5)$ to light-yellow. The aliquots were heated to $90^{\circ} \mathrm{C}$, chilled, filtered, heated again to $90^{\circ} \mathrm{C}$ and added to $10 \mathrm{~mL}$ of $\mathrm{CaCl}_{2}$ solution (5\%) with stirring till complete dissolution, and then chilled to $5{ }^{\circ} \mathrm{C}$ for $12 \mathrm{~h}$. Each solution was transferred to Falcon ${ }^{\circledR}$ tubes and centrifuged at $2500 \mathrm{rpm}$ for 5 minutes. The supernatant was discarded, the precipitate containing the oxalate was dissolved in $10 \mathrm{~mL}$ of $\mathrm{H}_{2} \mathrm{SO}_{4} 20 \%(\mathrm{v} / \mathrm{v})$ and then added $300 \mathrm{~mL}$ of distilled water. A $125 \mathrm{~mL}$ aliquot of each solution was heated to $90{ }^{\circ} \mathrm{C}$ and titrated with $\mathrm{KM}_{\mathrm{n}} \mathrm{O}_{4}$ solution $(0.05 \mathrm{M})$ until the color light pink persists for 30 seconds. The analysis was performed in triplicate. Calcium oxalate percentage was calculated by Equation 1 and the result was presented in mg of calcium oxalate/ $100 \mathrm{~g}$ of sample.

Ca oxalate(mg/100g) $=\frac{(D F) X / 0^{5}}{(M E) \times m f}(1)$

$\mathrm{V}=$ spent volume of $\mathrm{KMnO}_{4}(\mathrm{~mL}) ; \mathrm{V}_{\text {me }}=$ mass-equivalent volume $(1 \mathrm{~mL})$ of $\mathrm{KMnO}_{4} 0,05 \mathrm{M}$, solution = equivalent to $0,00225 \mathrm{~g}$ of anhydrous oxalic acid; $\mathrm{DF}=$ dilution factor $(2,4)$ obtained from dividing the total filtrate volume $(300 \mathrm{~mL})$ by the used aliquot $(125 \mathrm{~mL}) ; \mathrm{ME}=$ molar equivalent of $\mathrm{KMnO}_{4}$ in oxalate; $\mathrm{m}_{\mathrm{f}}=$ sample mass.

The content of vitamin $C$ was determined by Tillmans method (AOAC, 1990) using the solution of 2,6-dichlorophen-indophenol-sodium (DCFI) and 2\% 
oxalic acid. The percentage of chlorophyll was determined by Lichtenthaler method (1987); an aliquot (1 g) of leaves or petioles was macerated in mortar with $10 \mathrm{~mL}$ acetone solution $(80 \%)(\mathrm{v} / \mathrm{v})$ until all the pigmentation is extracted, then it was centrifuged at $4000 \mathrm{rpm}$ for $10 \mathrm{~min}$. The supernatant was transferred to a $25 \mathrm{~mL}$ volumetric flask. The volume was completed with acetone solution $(80 \%)(\mathrm{v} / \mathrm{v})$. Absorbance readings were performed in a UV-VIS spectrophotometer (Biochrom, Libra S60PC model) with $647 \mathrm{~nm}$ and $663 \mathrm{~nm}$ wave-length. P.A. acetone was used as negative control. Each sample was analyzed in triplicate. The results were expressed in $\mathrm{mg}$ of chlorophyll by $100 \mathrm{~g}$ of sample. The percentage of total chlorophyll was calculated by Equations 2, 3 and 4 (Lichtenthaler,1987).

$$
\begin{aligned}
& \text { Chlorophylla }=12,25\left(\mathrm{~A}_{663}\right)-2,79 \quad\left(\mathrm{~A}_{647}\right)(2) \\
& \text { Chlorophyllb }=21,50\left(\mathrm{~A}_{647}\right)-5,10\left(\mathrm{~A}_{663}\right) \text { (3) }
\end{aligned}
$$

\section{Tota 1}

$$
\text { chlorophyll }=7,15\left(\mathrm{~A}_{663}\right)+18,71\left(\mathrm{~A}_{647}\right)(4)
$$

$\mathrm{A}_{663}$ and $\mathrm{A}_{647}=$ absorbances at their respective wavelengths.

To analyze carotenoids, $2.5 \mathrm{~g}$ aliquots of leaves or petioles were macerated in mortar with celite $(0.5 \mathrm{~g})$ and cold P.A. acetone $\left(10^{\circ} \mathrm{C}\right)$. Carotenoid saturated acetone was being replaced by acetone P.A. until complete extraction, which was verified by depigmentation of the sample. Then the sample was vacuum filtered and transferred to a separation funnel containing previously $40 \mathrm{~mL}$ of petroleum ether P.A., obtaining a mixture of acetone + carotenoids + petroleum ether. The acetone was removed from the mixture by drag with distilled water by successive washings. The solution composed of Carotenoids and petroleum ether was transferred to a $50 \mathrm{~mL}$ volumetric flask and the volume was completed with petroleum ether (RodriguezAmaya, 1999). The absorbance of the extract was obtained using a UV-VIS spectrophotometer (Biochrom, Libra S60PC model) at $450 \mathrm{~nm}$ for total carotenoids and $470 \mathrm{~nm}$ for lycopenes, and petroleum ether used as negative control. The amounts of carotenoids and lycopenes were obtained by Equation 5 . The analysis was made in triplicate and the results expressed in $\mu \mathrm{g} / \mathrm{g}$ of sample.

Ca roten oids

contents $(\mu \mathrm{g} / \mathrm{g})=\frac{\mathrm{A} \times \mathrm{V} \times 10^{4}}{\mathrm{~A}_{1 \mathrm{~cm}}^{1 \%} \times \mathrm{M}}$

$\mathrm{A}=$ absorbance of the solution at the wavelength of $450 \mathrm{~nm}$ (total carotenoids) or $470 \mathrm{~nm}$ (lycopene); $\mathrm{V}=$ final volume final of the solution $(50 \mathrm{~mL}) ; A^{1 \%}{ }_{1 \mathrm{~cm}}=$ absorptivity factor in petroleum ether (2592 for beta-carotene or 3450 for lycopene); $\mathrm{M}=$ sample mass (g).

For the evaluation of phenolic compounds, the extract was obtained from the mixture of the sample $(5 \mathrm{~g})$ and the solvent in the ratio of $1: 5(\mathrm{~m} / \mathrm{v})$; the solvent was a 70:29.5:0.5 (v/v/v) mixture of acetone/water/acetic acid. The mixture was homogenized at $250 \mathrm{rpm}$ for $3 \mathrm{~h}$ in the absence of light at $25^{\circ} \mathrm{C}$ and centrifuged for $10 \mathrm{~min}$ at $1500 \mathrm{rpm}$. The supernatant was the extract whose absorbance was obtained at $765 \mathrm{~nm}$ in a UV-VIS spectrophotometer (Biochrom, Libra S60PC model), and distilled water was the negative control (Singleton and Lamuela Raventos, 1999). The amount of phenolic compounds in different concentrations of gallic acid (100 a $1000 \mu \mathrm{g} / \mathrm{mL}$ ) was calculated from the interpolation between absorbance values of a standard curve. The results were expressed in $\mathrm{mg}$ of equivalent gallic acid per gram of sample (mg AGE/g of sample).

To analyze the antioxidant activity the extract was prepared with $1 \mathrm{~g}$ of sample mixed to $40 \mathrm{~mL}$ of methanol solution $(50 \%)$ for $1 \mathrm{~h}$ in room temperature, centrifuged for $15 \mathrm{~min}$ and the supernatant transferred to $100 \mathrm{~mL}$ volumetric flask. $40 \mathrm{ml}$ of acetone $(70 \%)$ was added to the precipitant, homogenized and allowed to stand for $1 \mathrm{~h}$, then centrifuged for $15 \mathrm{~min}$. This second supernatant was transferred to the volumetric flask with the first one and the volume was completed com distilled water, resulting in the analyzed extract. From this 3-4 distilled water dilutions were prepared (Rufino et al., 2007a; 2007b).

Determination of antioxidant activity by DPPH was performed by adding $3.9 \mathrm{~mL}$ of the radical DPPH $(0.06 \mathrm{mM})$ and $0.1 \mathrm{~mL}$ of each extract dilution, the mixture being homogenized and read at $515 \mathrm{~nm}$ in a UV-VIS spectrophotometer (Biochrom, Libra model), and methyl alcohol P.A. as negative control. The same procedure was used to the control solution prepared with methyl alcohol $(50 \%)$, acetone $(70 \%)$ and distill water. The standard curve of DPPH was built using methyl alcohol in different concentrations $(10 \mu \mathrm{M}$ to $60 \mu \mathrm{M})$. The absorbance readings of each dilution were performed in triplicate. A linear regression was performed, and the result was obtained on concentration of antioxidant required to reduce the original quantity of free radicals by $50 \%\left(\mathrm{EC}^{50}\right)$; the value was expressed in $g$ of sample per $g$ of DPPH ( $\mathrm{g} / \mathrm{g}$ DPPH).

In the determination using the ABTS radical capture method $3.0 \mathrm{~mL}$ of ABTS radical and $30 \mu \mathrm{L}$ of each dilution of the extract were added, homogenized and incubated for $6 \mathrm{~min}$ sheltered from light; the absorbance was read in a $734 \mathrm{~nm}$ 
wavelength spectrophotometer. Ethylic alcohol P.A. was used as negative control. A standard curve was built with Trolox standard solution at different concentrations $(100 \mu \mathrm{M}$ to $2000 \mu \mathrm{M}$ ), and the results expressed as micromolar of Trolox per gram of sample ( $\mu \mathrm{M}$ trolox/g de amostra).

\section{Statistical analysis}

Mean of repetitions, standard deviation and variance analyzes (ANOVA) were used for statistical treatment of the samples, being the comparison of averages made by Tukey test to the level of significance of $5 \%$ by the software STATISTICA 8.0 (StatSoft, Inc, Tulsa, EUA, 2008).

\section{RESULTS AND DISCUSSION}

The contents of humidity $(88.58 \mathrm{~g} / 100 \mathrm{~g})$ and fixed mineral residue $(13.77 \mathrm{~g} / 100 \mathrm{~g})$ of the leaves were similar to Taioba leaves analyzed by Leterme et al., (2005), meanwhile the petiole showed higher contents of humidity (93.86 g/100g) and fixed mineral residue $(22.12 \mathrm{~g} / 100 \mathrm{~g})$ than the leaves as also shown by Pinto et al. (2001b) (Table 1). The high content of humidity in Taioba $(>70 \%)$ hinders its conservation restricting its commercialization in natura (Falade and Okafor, 2015).

Leaf calcium amount was $1.79 \mathrm{~g} / 100 \mathrm{~g}$ and the petiole showed $0.98 \mathrm{~g} / 100 \mathrm{~g}$ diverging the values reported in the literature; Oliveira et al. (2012) found lower values of calcium in fresh $(0.27 \mathrm{~g} / 100 \mathrm{~g})$ and cooked leaves (0.37 g/100g), while Pinto et al. (1999, 2001b) obtained $2.23 \mathrm{~g} / 100 \mathrm{~g}$ with the raw leaf and $1.54 \mathrm{~g} / 100 \mathrm{~g}$ with the petiole. Taioba calcium amount indicates that the species is an important source of the mineral and can be used as dietary or therapeutic supplement in the prevention and treatment of osteoporosis (Oliveira et al., 2012).

Osteoporosis is a silent disease that shows high mortality rates, related to insufficient calcium ingestion, being postmenopausal women and elderly the groups most likely to develop this deficiency (Radominski et al., 2017; Zhang et al., 2018). Dietary calcium recommendation for adults is 1-1.2g per day (Ross et al., 2011) what can be supplied by daily consumption of 56-67 g of leaves or 100-123 g of petioles.

The values obtained for magnesium are close to those found in the literature for leaves $(0.5 \mathrm{~g} / 100 \mathrm{~g})$ and petioles $(0.25 \mathrm{~g} / 100 \mathrm{~g})$ (Table 1$)$. Taioba leaves present large photosynthetic surface than petioles, therefore the levels of Magnesium are higher once it is the main constituent of chlorophyll (Saga and Tamiaki, 2012). From the functionality standpoint, high levels of Magnesium inside muscle cells improve their insulin sensitivity, since the mineral interferes in the composition of the cellular phospholipid layer (Jackiz, 2015).

Lipids showed higher levels in leaf $(7.60 \mathrm{~g} / 100 \mathrm{~g})$ than in petiole with values close to those obtained by Leterme et al. (2005). In relation to petioles, the values were higher than the ones found by Pinto et al. (2001b), which was $1.88 \mathrm{~g} / 100 \mathrm{~g}$. Overall, plants have low lipid content in vegetative organs, such as leaves.

Protein levels in leaves were higher than the reported in the literature (Leterme et al., 2005; Pinto et al., 1999, 2001b), differences that may be related to different growing conditions, climate, soil and plant genetic (Gonçalves, 2000). Besides, the concentration of nutrients in the plant varies due to the kind of tissue is being analyzed and the phenological stage (Robinson, 2005). Resolution n.269 of National Health Surveillance Agency (ANVISA, 2005) recommends daily consumption of $50 \mathrm{~g}$ of protein for adults and $34 \mathrm{~g}$ for children up to 10 years-old. Ingestion of $50 \mathrm{~g}$ of Taioba leaves can provide $60 \%$ the recommended daily intake of protein for adults and $86 \%$ for children.

Table 1: Nutritional composition and calcium oxalate amount of leaf and petiole of $X$. sagittifolium (L.) Schott

\begin{tabular}{|c|c|c|c|c|c|}
\hline \multirow[t]{2}{*}{ Constituents (g/100g) } & \multicolumn{3}{|c|}{ Leaf } & \multicolumn{2}{|c|}{ Petiole } \\
\hline & $\begin{array}{l}\text { Current } \\
\text { study }\end{array}$ & $\begin{array}{c}\text { Leterme } \\
\text { et al., (2005) }\end{array}$ & $\begin{array}{l}\text { Pinto et al., } \\
\text { (1999; 2001b) }\end{array}$ & $\begin{array}{l}\text { Current } \\
\text { study }\end{array}$ & $\begin{array}{l}\text { Pinto et al., } \\
\text { (1999; 2001b) }\end{array}$ \\
\hline Humidity* & $88.58 \pm 0.10^{b}$ & 86.1 a 90.1 & 89.74 & $93.86 \pm 0.16^{a}$ & 94.39 \\
\hline Fixed mineral residue & $13.77 \pm 0.39^{b}$ & 11.5 a 13.9 & 15.03 & $22.12 \pm 1.04^{\mathrm{a}}$ & 17.95 \\
\hline Calcium & $1.79 \pm 0.06^{a}$ & $1.97-2.62$ & 2.23 & $0.98 \pm 0.17^{a}$ & 1.54 \\
\hline Magnesium & $0.50 \pm 0.004^{a}$ & $0.37-0.73$ & 0.27 & $0.25 \pm 0.004^{a}$ & 0.16 \\
\hline Proteins & $58.50 \pm 1.66^{a}$ & 23.1 a 24.0 & 27.59 & $30.90 \pm 0.32^{b}$ & 10.62 \\
\hline Lipids & $7.60 \pm 0.68^{a}$ & 8.0 a 9.7 & 6.00 & $5.86 \pm 0.48^{b}$ & 1.88 \\
\hline Gross fiber & $23.39 \pm 0.90^{\mathrm{a}}$ & 12.4 a 13.0 & 15.53 & $16.66 \pm 0.43^{b}$ & 19.00 \\
\hline Carbohydrates & $8.70 \pm 2.11^{b}$ & 19.7 a 22.9 & 30.29 & $34.99 \pm 0.86^{a}$ & 41.58 \\
\hline Calcium Oxalate** & $648^{b}$ & -- & -- & $846.72^{a}$ & - \\
\hline
\end{tabular}

${ }^{*}$ Humidity and calcium oxalate were determined in wet basis. The others were analyzed in $100 \mathrm{~g}$ of dry mass. ${ }^{* *}$ calcium oxalate expressed in mg/100g. Values expressed within means and standard deviation $(n=3)$, equal letters in the same line means they do not diverge significantly among them at $5 \%$ ( $>0.05)$ by Tukey Test 
Regarding the fibers, the values obtained for the leaf were higher than those reported by Leterme et al. (2005), while in the petiole the value obtained $(16.66 \mathrm{~g} / 100)$ was lower than that reported by Pinto et al. (2001b). Fiber consumption is relevant for human health improving intestinal motility (Bernaud and Rodrigues, 2013). Besides that, it helps in the treatment of Diabetes Mellitus, reducing blood glucose (Carvalho et. al., 2017), and obesity (Post et al., 2012), contributing to reduce the risk of both cardiovascular and coronary diseases once it is related to the improvement of modifiable risk factors such as hypertension and hypercholesterolemia (Threapleton et al., 2013). Recommended daily consumption of fiber is 38 and $25 \mathrm{~g} /$ day for men and women, respectively (Jackix, 2013), what means that $100 \mathrm{~g}$ of Taioba leaves can provide $61 \%$ and $93.56 \%$ of recommended daily value.

The amount of carbohydrates in the petiole $(34.99 \mathrm{~g} / 100 \mathrm{~g})$ was higher than the leaf $(8.70 \mathrm{~g} / 100 \mathrm{~g})$; Leterme et al. (2005) reported values between $19.7 \mathrm{~g} / 100 \mathrm{~g}$ and $22.9 \mathrm{~g} / 100 \mathrm{~g}$ for Taioba leaves and Pinto et al. (2001b) reported $41.58 \mathrm{~g} / 100 \mathrm{~g}$ in the petiole and $30.29 \mathrm{~g} / 100 \mathrm{~g}$ in leaf blades. The difference can occur due to hydrolysis of carbohydrates from reserve tissues (petiole) and their transportation to aerial parts (leaf blades) to be used in plant metabolism explaining the variation as the result of metabolic activity in the moment of sampling (Santos et al., 2014).

Other leafy vegetables such as lettuce (Lactuca sativa L.), spinach (Tetragonia expansa), broccoli (Brassica oleracea var. italica), cabbage (Brassica oleracea var. acephala) and arugula (Eruca sativa L.) present, on average, lower values of nutritional constituents than Taioba (Table 2) (Lima, 2011).

Calcium Oxalate present in various food crops such as spinach, rhubarb, chard, beets, tomatoes, nuts and cocoa (Scardelato et al., 2013) is considered an anti-nutritional factor because it causes reduced availability of Calcium (Liu et al., 2018). Calcium oxalate amount was $648 \mathrm{mg} / 100 \mathrm{~g}$ in Taioba leaves which is lower than the value found in spinach (822 mg/100g) by Franco (1986), while in the petiole these values were higher than the leaf blades $(846.72 \mathrm{mg} / 100 \mathrm{~g})$. Calcium oxalate acts as a protection factor of the plant against herbivory, and the petiole can serve as a reserve of that substance (Saito and Lima, 2009). One way to reduce the quantity of oxalate is by cooking (Oliveira et al., 2012; Lima and Krupek, 2016; Liu et al., 2018) since calcium oxalate is soluble in water and migrates during cooking to the water, reducing its content by leaching and making the leaves of Taioba a safe food for consumption (Seganfredo et al., 2001).

Vitamin C contents presented a significant difference ( $p>0.05$ ) between leaf blade $(87 \mathrm{mg} / 100 \mathrm{~g})$ and the petiole (83 mg/100g), with higher value for the leaf blades (Table 3). Leterme et al. (2005) and Pinto et al. (2001b) found $40 \mathrm{mg} / 100 \mathrm{~g}$ in leaf blades, while for the petiole Pinto et al. (2001b) found $19 \mathrm{mg} / 100 \mathrm{~g}$. The differences obtained in relation to these studies may be related to the storage temperature, the stage of development of the plant and the respective part of the plant analyzed (Rivelli et al., 2017). The values reported at the present study can be compared with the orange considered a reference because it presents 40 to $70 \mathrm{mg} / 100 \mathrm{~g}$ of this vitamin (Pinto et al., 2001b; Lima, 2011). The amount of vitamin $C$ in Taioba was higher than conventional leafy vegetables as lettuce $(21.4 \mathrm{mg} / 100 \mathrm{~g})$, broccoli $(34.3 \mathrm{mg} / 100 \mathrm{~g})$, cauliflower $(36.1 \mathrm{mg} / 100 \mathrm{~g})$, spinach $(2.4 \mathrm{mg} / 100 \mathrm{~g})$, cabbage $(18.7 \mathrm{mg} / 100 \mathrm{~g})$ and arugula (46.3 mg/100g) (Lima, 2011).

The values obtained for carotenoids in Taioba leaf were lower $(83.19 \mathrm{mg} / 100 \mathrm{~g})$ than those reported for common sorrel (Rumex acetosa) $95.64 \mathrm{mg} / 100 \mathrm{~g}$ by Viana et al. (2015), reinforcing what Kobori and Rodriguez-Amaya (2008) affirm about the leaves of unconventional Brazilian food plants, which generally present a higher concentration of carotenoids than common leafy vegetables such as parsley $(0.07 \mathrm{mg} / 100 \mathrm{~g})$ and coriander $(0.05 \mathrm{mg} / 100)$ considered important sources of carotenoids.

Total chlorophyll amount was similar between leaf blade and petiole of Taioba (Table 3); Ozkan and Bilek (2015) obtained $11.36 \pm 0,17 \mathrm{mg} / 100 \mathrm{~g}$ of chlorophyll in fresh leaves of spinach. Regarding lycopene Taioba leaves presented higher levels $(31 \mathrm{mg} / 100 \mathrm{~g})$ when compared to Pereskia grandifolia $(6.44 \pm 1.32 \mathrm{mg} / 100 \mathrm{~g})$ studied by Almeida

Table 2: Nutritional composition of conventional leafy vegetables (Lima 2011)

\begin{tabular}{lccccc}
\hline Constituent $(\mathbf{g} / \mathbf{1 0 0 g})$ & \multicolumn{3}{c}{ Conventional leafy vegetables } \\
\cline { 2 - 5 } & Lettuce & Spinach & Broccoli & Cabbage & Arugula \\
\hline Fixed mineral residue & 0.8 & 1.2 & 0.8 & 1.3 & 0.13 \\
Calcium & 0.03 & 0.1 & 0.09 & 0.03 & 0.12 \\
Magnesium & 0.01 & 0.08 & 0.03 & 2.9 & 0.02 \\
Protein & 1.7 & 2.0 & 3.6 & 0.5 & 3.8 \\
Lipids & 0.1 & 0.2 & 2.9 & 3.1 & 0.1 \\
Gross fiber & 2.3 & 2.1 & 4.0 & 4.3 & 2.2 \\
Carbohydrates & 2.4 & 2.6 & & & 4 \\
\hline
\end{tabular}


Table 3: Bioactive compounds (vitamin C, chlorophyll, carotenoids e lycopene) of leaf blade and petiole of $X$. sagittifolium (L.) Schott

\begin{tabular}{lcccc}
\hline Bioactive compounds & Leaf blade & & Petiole \\
\cline { 2 - 2 } & Mean \pm SD & & Mean \pm SD \\
\hline Vitamin C (mg/100g)) & $87 \pm 0.79^{\mathrm{a}}$ & & $83 \pm 1.27^{\mathrm{b}}$ \\
Total carotenoids $(\mathrm{mg} / 100 \mathrm{~g})$ & $83.19 \pm 0.54^{\mathrm{a}}$ & & $54.07 \pm 0.70^{\mathrm{b}}$ \\
Lycopene $(\mathrm{mg} / 100 \mathrm{~g})$ & $31 \pm 0.51^{\mathrm{a}}$ & & $20 \pm 0.39^{\mathrm{b}}$ \\
Total chlorophyll $(\mathrm{mg} / 100 \mathrm{~g})$ & $8.94 \pm 0.02^{\mathrm{a}}$ & & $7.0 \pm 0.15^{\mathrm{a}}$ \\
Phenolic compounds $(\mathrm{mg} \mathrm{AGE} / \mathrm{g})$ & $5.33 \pm 0.18^{\mathrm{a}}$ & & $2.80 \pm 0.04^{\mathrm{b}}$ \\
\hline
\end{tabular}

${ }^{*}$ In dry basis. Values show mean and standard deviation $(n=3)$, equal letters in the same line means they do not diverge significantly among them at $5 \%(p>0,05)$ by Tukey Test

Table 4: Antioxidant activity of leaf and petiole of Taioba obtained by radical sequestration of $\mathrm{DPPH}^{*}$ and $\mathrm{ABTS}{ }^{* *}$

\begin{tabular}{lccc} 
Constituints & \multicolumn{1}{c}{ Leaf } & & Petiole \\
\cline { 2 - 2 } & Mean \pm SD & & Mean \pm SD \\
\hline ABTS $(\mu$ M trolox/g) & $26.48 \pm 0.23^{\mathrm{a}}$ & & $17.25 \pm 0.17^{\mathrm{b}}$ \\
EC $_{50}$ DPPH $(\mathrm{g} / \mathrm{g}$ DPPH $)$ & $0.72 \pm 0.00^{\mathrm{b}}$ & & $1.43 \pm 0.01^{\mathrm{a}}$ \\
\hline
\end{tabular}

Values show mean and standard deviation $(n=3)$, equal letters in the same line means they do not diverge significantly among them at $5 \%(p>0.05)$ by Tukey Test.

et al. (2014). Rodriguez-Amaya (2008) assert that foods which contain more than $2 \mathrm{mg} / 100 \mathrm{~g}$ of carotenoids are considered important to health.

The values of phenolic compounds of Taioba differed significantly between leaf blade and petiole (Table 3), the leaves having the highest values (5.33 mg AGE/g). These compounds (phenolic acids, tannins and flavonoids) are one of the greater classes of secondary metabolites found in plants (Viana et al., 2015), being a complex composition of phytochemicals that varies according to the method of cultivation, the presence of Oxygen, the luminous intensity, the temperature and the type of soil (Jackix, 2015). Arruda et al. (2004) evaluated the capacity of Xanthosoma sagittifolium leaves in reducing the oxidative stress induced by vitamin A deficiency evidencing the protective effect of the leaf against the lipid peroxidation, caused by the deficiency of this vitamin. This beneficial effect may be related to the content of carotenoids, phenolic compounds and other antioxidant compounds, such as vitamin C.

The most common natural pigments in leafy vegetables are chlorophyll and carotenoids, being the carotenoids responsible for the color diversity in plants, providing protective effects for human health (Hounsome et al., 2008; Volp et al., 2009; Agbaire, 2011). These compounds are assigned antimutagenic (Volp et al., 2009; Osuna-Ruiz et al., 2016) and antigenotoxic properties (Serpeloni et al., 2013; Osuna-Ruiz et al., 2016) besides helping to correct dyslipidemia and to be antioxidants (Volp et al., 2009; Osuna-Ruiz et al.,2016). $\beta$-carotene and chlorophyll can still be used as natural colorants in food products (Medeiros et al., 2012; Ozkan and Bilek, 2015).
The leaves showed higher antioxidant activity $(26.48 \mu \mathrm{M}$ trolox $/ \mathrm{g}$ and $0.72 \mathrm{~g} / \mathrm{g} \mathrm{DPPH}$ ) than the petioles in both employed methods (ABTS and DPPH) (Table 4). Dos Reis et al. (2015) have analyzed the antioxidant activity of broccoli and cauliflower reporting respectively the values $0.03 \pm 0.03$ and $0.016 \pm 0.67 \mathrm{~g}$ of sample/g of DPPH. Suresh et al. (2017) have showed that the broccoli extract has antioxidant potential in the pancreatic tissue of diabetic rats, suggesting that leaves and petioles of Taioba could also present antioxidant action.

In addition to the nutritional and functional properties useful to human health, Taioba has its optimum development in the rainy summer period, when conventional leafy vegetables have growing difficulties (Seganfredo et al., 2001); its adaptability to higher temperatures and moist soils (MAPA, 2010) show its food potential that can be harnessed to combat malnutrition, propitiate new flavors and increase nutritional content in food mixtures. Taioba combines nutritional characteristics superior to most conventional vegetables and can be consumed safely opening perspectives of use not only in the domestic menu, but also as raw material for the elaboration of functional food products.

\section{ACKNOWLEDGMENTS}

National Council of Scientific and Technological Development - CNPQ and FUNDECT for financial support for the laboratory infrastructure.

\section{Authors' contributions}

Sarah Araújo designed and did the experiment with the help of Priscila Araújo and Aline Giunco. Eliana SanjinezArgandona designed the experiment and contributed to the preparation of the manuscript in Portuguese. Sandro Menezes Silva contributed with the determination and registration of the species, preparation of the manuscript in Portuguese and the English version.

\section{REFERENCES}

Agbaire, P. O. 2011. Nutritional and anti-nutritional levels of some local vegetables (Vernomia anydalira, Manihot esculenta, Teiferia occidentalis, Talinum triangulare, Amaranthus spinosus) from delta state, Nigeria. J. Appl. Sci. Environ. Manage. 15: 625-628.

Almeida, M. E. F., A. M. B. Junqueira, A. A. Simão and A. D. Corrêa. 2014. Caracterização química das hortaliças não- convencionais conhecidas como ora-pro-nóbis. Biosci. J. 30: 431-439.

AOAC. 1990. Official Methods of Analysis of AOAC International. 16th ed. AOAC International, Arlington, Virginia, USA.

AOAC. 2003. Official Methods of Analysis of AOAC International. 17th ed. AOAC International, Arlington, Virginia, USA.

AOAC. 2005. Official Methods of Analysis of AOAC International. 18th ed. AOAC International, Arlington, Virginia, USA. 
Arruda, S. F., E. M. A. Siqueira and E. M. T. Souza. 2004. Malanga (Xanthosoma sagittifolium) and Purslane (Portulaca oleracea) leaves reduce oxidative stress in Vitamin A deficient rats. Ann. Nutr. Metab. 48: 288-295.

Arruda, A. P. and G. S. Hotamisligil. 2015. Calcium homeostasis and organelle function in the pathogenesis of obesity and diabetes. Cell Metab. 22: 381-397.

Bernaud, F. S. R. and T. C. Rodrigues. 2013. Fibra alimentar ingestão adequada e efeitos sobre a saúde do metabolismo. Arq. Bras. Endocrinol. Metab. 57: 397-405.

ANVISA. 2005. Agência Nacional de Vigilância Sanitária, Departamento do Ministério da Saúde, Regulamento Técnico Sobre a Ingestão Diária Recomendada (IDR) de Proteína, Vitaminas E Minerais, Resolução RDC n² 269, Brasil.

MAPA. 2010. Ministério da Agricultura, Pecuária e Abastecimento, Secretaria de Desenvolvimento Agropecuário e Cooperativismo. Manual de Hortaliças, Brasil.

Carvalho, C. M., T. P. Paula, L. V. Viana, V. M. T. Machado, J. C. Almeida and M. J. Azevedo. 2017. Plasma glucose and insulin responses after consumption of breakfasts with different sources of soluble fiber in Type 2 diabetes patients: A randomized crossover clinical trial. Am. J. Clin. Nutr. 106: 1238-1245.

Caxito, M. L. C., R. R. Correia, A. C. C. Gomes, G. Justo, M. G. P. Coelho, C. M. Sakuragui, R. M. Kuster and K. C. C. Sabino. 2015. In vitro Antileukemic activity of Xanthosoma sagittifolium (Taioba) leaf extract. Evid. Based Compl. Alternat. Med. 1: 1-10.

Dos Reis, L. C. R., V. R. Oliveira, M. E. K. Hagen, A. Jablonski, S. H. Flôres and A. O. Rios. 2015. Carotenoids, flavonoids, chlorophylls, phenolic compounds and antioxidant activity in fresh and cooked broccoli (Brassica oleracea var. Avenger) and cauliflower (Brassica oleracea var. Alphina F1). J. Food Sci. Technol. 63: 177-183.

Falade, K. O. and C. A. Okafor. 2015. Physical, functional and pasting properties of flours from corms of two Cocoyam (Colocasia esculenta and Xanthosoma sagittifolium) cultivars. J. Food Sci. Technol. 52: 3440-3448.

Franco, G. 1986. Tabela de Composição Química dos Alimentos. Editora Atheneu, Rio de Janeiro.

Gonçalves, E. G. 2000. Xanthosoma riparium (Araceae), a New species from Goias, Brazil. Novon. 10: 26-28.

Heredia, Z. N. A., M. C. Vieira and B. A. Pontim. 2005. Arranjo de plantas na produção do mangarito (Xanthosoma mafaffa Schott) 'comum'. Acta Sci Agron. 27: 409-413.

Hounsome, N., B. Hounsome, D. Tomos and G. Edwards-Jones. 2008. Plant metabolites and nutritional quality of vegetables. J. Food Sci. 73: 48-65.

Iwoha, C. I. and F. A. Kalu. 1995. Calcium oxalate and physicochemical properties of cocoyam (Colocasia esculenta and Xanthosoma sagittifolium) tuber flours as affected by processing. Food Chem. 54: 61-66.

Jackix, E. A. 2015. Propriedades funcionais de vegetais e efeitos da folha de taioba (Xanthosoma sagittifolium) sobre a saúde. Rev. Bras. Nutr. Funct. 15: 31-38. [Kindly provid in English language]

Jackix, E. A., E. B. Monteiro, H. Raposo and J. Amaya-Farfán. 2013. Cholesterol reducing and bile acid binding properties of taioba (Xanthosoma sagittifolium) leaf in rats fed a high-fat diet. Food Res. Int. 51: 886-891.

Jahnen-Dechent, W. and M. Ketteler. 2012. Magnesium basics. Clin. Kidney J. 5: i3-i14.

Kinupp, V. F. and I. B. I. Barros. 2008. Teores de proteína e minerais de espécies nativas, potenciais hortaliças e frutas. Ciênc. Tecnol. Aliment. 28: 846-857. [Kindly provid in English language ]
Kinupp, V. F. and H. Lorenzi. 2014. Plantas Alimentícias Não Convencionais (PANC) No Brasil: Guia de Identificação, Aspectos Nutricionais e Receitas llustradas. Editora Instituto Plantarum de Estudos da Flora, São Paulo.

Kobori, C. N. and D. B. Rodriguez-Amaya. 2008. Native Brazilian green Leary vegetables are richer sources of carotenoids than commercial leafy vegetables. Food Nutr. Bull. 29: 333-341.

Leterme, P., A. M. Londoño, F. Estrada and W. B. Soufrant. 2005. Chemical composition, nutritive value and voluntary intake of tropical tree foliage and cocoyam in pigs. J. Sci. Food Agric. 85: $1725-1732$.

Lichtenthaler, H. K. 1987. Chlorophylls and carotenoids: Pigments of photosynthetic biomembranes. Methods Enzymol. 148: 350-381.

Lima, A. S. G. and R. A. Krupek. 2016. Caracterização morfológica, anatômica, e toxinas endógenas em Colocasia esculenta (L.) Schott e Xanthosoma sagittifolium (L.) Schott. Luminária. 18: $31-40$.

Lima, D. M. 2011. Tabela de Composição de Alimentos TACO. Editora NEPA, UNICAMP, São Paulo.

Liu, T., D. J. Burritt, G. T. Eyres and I. Oey. 2018. Pulsed electric field processing reduces the oxalate content of oca (Oxalis tuberosa) tubers while retaining starch grains and the general structural integrity of tubers. Food Chem. 245: 890-898.

Malavolta, E., G. C. Vitti and S. A. Oliveira. 1997. Avaliação do Estado Nutricional das Plantas: Princípios e Aplicações. Editora POTAFOS, Piracicaba.

Medeiros, G. R., A. Kwiatkowski and E. Clemente. 2012. Características de qualidade de farinhas mistas de trigo e polpa de pupunha (Bactris gasipaes Kunth). Aliment. Nutri. 23: 655-660.

Oliveira, G. L., L. H. C. Andrade and A. F. M. Oliveira. 2012. Xanthosoma sagittifolium and Laportea aestuans: Species used to prevent osteoporosis in Brazilian traditional medicine. Pharm. Biol. 50: 930-932.

Ozkan, G. and S. E. Bilek. 2015. Enzyme-assisted extraction of stabilized chlorophyll from spinach. Food Chem. 176: 152-157.

Osuna-Ruiz, I., C. López-Saiz, A. Burgos-Hernández, C. Velázquez, M. Nieves-Soto and M. A. Hurtado-Oliva. 2016. Antioxidant, antimutagenic and antiproliferative activities in selected seaweed species from Sinaloa, Mexico. Pharm. Biol. 54: 2196-2210.

Pérez, E. E., M. E. Gutiérrez and E. P. Dedelahaye. 2007. Production and characterization of Xanthosoma sagittifolium and Colocasia esculenta flours. J. Food Sci. 72: 367-371.

Pinto, N. A. V., V. D. Carvalho, A. D. Corrêa and A. O. Rios. 2001a Avaliação de fatores antinutricionais das folhas da taioba (Xanthosoma sagittifolium schoot). Ciênc. Agrotec. 25: 601-604.

Pinto, N. A. V., S. M. Fernandes, P. M. P. and V. D. Carvalho. 2001b. Variabilidade da composição centesimal, Vitamina C, ferro e cálcio de partes da folha de taioba (Xanthosoma sagittifolium Schott). Rev. Bras. Agrociênc. 7: 205-208.[Kindly provid in English language ]

Pinto, N. A. V., B. M. V. Boas and V. D. Carvalho. 1999. Caracterização mineral das folhas de taioba (Xanthosoma sagittifolium Schott). Ciên. Agrotec. 23: 57-61.

Post, R. E., A. G. 3rd. Mainous, D. E. King and K. N. Simpson. 2012. Dietary fiber for the treatment of Type 2 diabetes mellitus: A meta-analysis. J. Am. Board Fam. Med. 25: 16-23.

Radominski, S. C., W. Bernardo, A. P. Paula, B. H. Albergariad, C. Moreirae, C. E. Fernandes, C. H. M. Castro, C. A. F. Zerbini, D. S. Domicianoi, L. M. C. Mendonca, L. M. Pompeif, M. C. Bezerrak, M. A. R. Loures, M. C. O. Wender, M. Lazaretti- 
Castro, R. M. R. Pereirai, S. S. Maedag, V. L. Szejnfeldg and V. Z. C. Borbaa. 2017. Diretrizes brasileiras para o diagnóstico e tratamento da osteoporose em mulheres na pós-menopausa. Rev Bras. Reumatol. 57: S452-S466.

Rivelli, A. R., M. C. Caruso, S. Maria and F. Galgano. 2017. Vitamin C content in leaves and roots of horseradish (Armoracia rusticana): Seasonal variation in fresh tissues and retention as affected by storage conditions. Emirates. J. Food Agric. 29: 799-806.

Robinson, J. B. 2005. Critical plant tissue values and aplication of nutritional standards for practical use in vineyards: Proceedings of the soil environment and vine mineral nutrition symposium. Am. Soc. Enol. Vit. 29: 61-68.

Rodriguez-Amaya, D. B. 1999. A Guide to Carotenoid Analysis in Foods. Institute Press, Washington., DC.

Rodriguez-Amaya, D. B. 2008. Fontes Brasileiras de Carotenoides: Tabela Brasileira de Composição de Carotenoides em Alimentos. MMA/SBF, Brasília.

Ross, A. C., J. E. Manson, S. A. Abrams, J. F. Aloia, P. M. Brannon, S. K. Clinton, R. A. Durazo-Arvizu, J. C. Gallagher, R. L. Gallo, G. Jones, C. S. Kovacs, S. T. Mayne, C. J. Rosen and A. S. Shapses. 2011. The report on dietary reference intakes for calcium and Vitamin $D$ from the institute of medicine: What clinicians need to know. J. Clin. Endocrinol. Metab. 96: 53-58.

Rufino, M. S. M., R. E. Alves, E. S. Brito, S. M. Morais, C. G. Sampaio, J. P. Jimenez and F. D. S. Calixto 2007a. Determinação da Atividade Antioxidante Total em Frutas Pela Captura do Radical Livre ABTS.+. Comunicado Técnico Embrapa, Fortaleza.

Rufino, M. S. M., R. E. Alves, E. S. Brito, S. M. Morais, C. G. Sampaio, J. P. Jimenez and F. D. S. Calixto 2007b. Determinação da Atividade Antioxidante total em Frutas Pela Captura do Radical Livre DPPH. Comunicado Técnico Embrapa, Fortaleza.

Saga, Y. and H. Tamiaki. 2012. Demetalation of chlorophyll pigments. Chem. Biodivers. 9: 1659-1983.

Santos, W. M., S. S. Junior, F. Nolasco, R. A. S. Campos, M. B. Silva and L. F. O. Rodrigues. 2014. Produção de mudas de taioba em função do tipo e seccionamento de rizomas. Rev. Cient. 42: 74-79.

Scardelato, J. A., V. H. P. Legramandi and L. V. S. Sacramento. 2013. Ocorrência de cristais em plantas medicinais utilizadas no tratamento da nefrolitíase: Paradoxo?. J. Basic Applied Pharm.
Sci. 34: 161-168.

Seganfredo, R., F. L. Finger, R. S. Barros and P. R. Mosquim. 2001. Influência do momento da colheita sobre a deterioração póscolheita em folhas de taioba. Rev. Hortic. 19: 316-319.

Serpeloni, J. M., B. L. Batista, J. P. Angeli, G. R. Barcelos, M. L. Bianchi, F. J. Barbosa and L. M. Antunes. 2013. Antigenotoxic properties of Chlorophyll B against cisplatin-induced DNA damage and its relationship with distribution of platinum and magnesium in vivo. J. Toxicol. Environ. Health. 76: 345-353.

Singleton, V. L. and R. M. Lamuela-Raventos. 1999. Analysis of total phenols and other oxidation substrates and antioxidants by means of Folin-Ciocalteu reagent. Methods Enzymol. 299: 152-178.

Souza, C. S. 2008. Propagação in vitro de Germoplasma de Taioba (Xanthosoma sagittifolium (L.) Schott). (Dissertação de Mestrado), Universidade Federal de Viçosa, Minas Gerais.

Statsoft, Inc. 2008. Software: Versão 8.0. Statsoft, Tulsa.

Suresh, S., M. I. Waly, M. S. Rahman, N. Guizani, M. A. B. AlKindi, H. K. A. Al-lssaei, S. N. M. Al-Maskari, B. R. S. AlRuqaishi and A. Al-Salami. 2017. Broccoli (Brassica oleracea) reduces oxidative damage to pancreatic tissue and combats hyperglycaemia in diabetic rats. Prev. Nutri. Food Sci. 22: 277-284.

Threapleton, D. E., D. C. Greenwood, C. E. Evans, E. L. Charlotte, C. L. Cleghorn, C. Nykjaer, C. Woodhead, J. E. Cade, C. P. Gale and V. J. Burley. 2013. Dietary fibre intake and risk of cardiovascular disease: Systematic review and meta-analysis. BMJ. 347: f6879.

Viana, M. M. S., L. A. Carlos, E. C. Silva, S. M. F. Pereira, D. B. Oliveira and M. L. V. Assis 2015. Phytochemical composition and antioxidant potential of unconventional vegetables. Hortic. Bras. 33: 504-509.

Volp, A. C. P., I. R. T. Renhe and P. C. Stringueta, P. C. 2009 Pigmentos naturais bioativos. Aliment. Nutr. 20: 157-166.

Wang, J., P. Um, B. A. Dickerman and J. Liu. 2018. Zinc, Magnesium, selenium and depression: A review of the evidence, potential mechanisms and implications. Nutrients. 10: 584.

Zhang, W., G. J. Yang, S. X. Wu, D. Q. Li, Y. B. Xu, C. H. Ma, J. L. Wang and W. W. Chen. 2018. The guiding role of bone metabolism test in osteoporosis treatment. Am. J. Clin. Exp. Immunol. 7: 40-49. 